ECONOMIC AND REGIONAL STUDIES

STUDIA EKONOMICZNE I REGIONALNE

ISSN 2083-3725

Volume 10, No. 1, 2017
Authors' contribution/

Wkład autorów:

A. Zaplanowanie badań/

Study design

B. Zebranie danych/

Data collection

C. Analiza statystyczna/

Statistical analysis

D. Interpretacja danych/

Data interpretation

Manuscript preparation

F. Opracowanie

piśmiennictwa/

Literature search

G. Pozyskanie funduszy/

Funds collection
E. Przygotowanie tekstu/

\section{TERRITORIAL AND SOCIAL DIVERSITY OF SOCIAL SECURITY IN POLAND IN YEARS 2010-2014}

\section{TERYTORIALNE I SPOŁECZNE ZRÓŻNICOWANIE BEZPIECZEŃSTWA SOCJALNEGO W POLSCE W LATACH 2010-2014}

\author{
Anna Iwacewicz-0rłowska
}

University of Finance and Management in Białystok Wyższa Szkoła Finansów i Zarządzania w Białymstoku

Iwacewicz-Orłowska A. (2017), Territorial and social diversity of social security in Poland in years 20102014/ Terytorialne i społeczne zróżnicowanie bezpieczeństwa socjalnego w Polsce w latach 2010-2014. Economic and Regional Studies. Vol. 10, No. 1, pp. 5-20. https://doi.org/10.2478/ers-2017-0001

\section{Summary}

ORIGINAL ARTICLE

JEL code: D63, I31

Submitted:

August 2016

Accepted:

November 2016

Tables: 10

Figures: 2

References: 21

\section{ORYGINALNY ARTYKUŁ} NAUKOWY

Klasyfikacja JEL: D63, I31

Zgłoszony:

sierpień 2016

Zaakceptowany:

listopad 2016

Tabele: 10

Rysunki: 2

Literatura: 21
Subject and purpose of work: The discussion undertaken in this article concerns differences in the level of social security. The main aim is to analyse the territorial and social diversity of social security in Poland in years 2010-2014.

Materials and methods: The research study presented was carried out on the basis of the analysis and synthesis of literature, statistical data, as well as the author's reflections.

Results: Differences in the level of social security to a large extent depend on the following factors: the territorial location and the size of the locality, age group, types of socio-economic groups, and type of household. Social security level is diversified territorially and socially.

Conclusions: The residents of small cities from the north-east part of the country and people aged between 16-24 are most threatened with poverty. In the case of Poland a high percentage of poverty threat is a matter of concern amongst working people. The lowest poverty level is in the group of 55year olds, that is people receiving retirement benefits.

Keywords: social security, poverty, income inequality, Gini coefficient

\section{Streszczenie}

Przedmiot i cel pracy: Rozważania podjęte w artykule dotyczą różnic w poziomie bezpieczeństwa socjalnego. Praca ma na celu analizę zróżnicowania terytorialnego oraz społecznego bezpieczeństwa socjalnego w Polsce w latach 2010-2014.

Materiały i metody: Praca została wykonana na podstawie analizy i syntezy literatury przedmiotu, zebranych danych statystycznych oraz własnych przemyśleń autorki.

Wyniki: Różnice w poziomie bezpieczeństwa socjalnego zależą w duży stopniu od następujących czynników: położenia terytorialnego oraz wielkości miejscowości, od grupy wiekowej, grupy społeczno-ekonomicznej oraz typu gospodarstwa domowego. Poziom bezpieczeństwa socjalnego jest więc zróżnicowany terytorialnie oraz społecznie.

Wnioski: Najbardziej zagrożeni ubóstwem są mieszkańcy małych miast leżących w północno-wschodniej części kraju oraz osoby w przedziale wiekowym 16-24 lata. W przypadku Polski niepokój budzi także wysoki odsetek zagrożenia ubóstwem osób pracujących. Najniższy poziom ubóstwa notowany jest w grupie osób powyżej 55 roku życia, czyli osób pobierających świadczenia emerytalne.

Słowa kluczowe: bezpieczeństwo społeczne, ubóstwo, nierówności dochodowe, wskaźnik Giniego

Address for correspondence/ Adres korespondencyjny: dr Anna Iwacewicz-Orłowska, Wyższa Szkoła Finansów i Zarządzania w Białymstoku, ul. Ciepła 40, 15-472 Białystok, Polska; tel. +48 692464 884; e-mail: anna.orlowska@wsfiz.edu.pl

Journal indexed in/ Czasopismo indeksowane w: AgEcon Search, AGRO, BazEkon, Index Copernicus Journal Master List, ICV 2015: 81,26; Polish Ministry of Science and Higher Education 2016: 9 points/ AgEcon Search, AGRO, BazEkon, Index Copernicus Journal Master List ICV 2015: 81,26; Ministerstwie Nauki i Szkolnictwa Wyższego 2016: 9 punktów. Copyright: (C) 2016 Pope John Paul II State School of Higher Education in Biała Podlaska, Anna Iwacewicz-Orłowska. All articles are distributed under the terms of the Creative Commons Attribution-NonCommercial-ShareAlike 4.0 International (CC BY-NC-SA 4.0) License (http://creativecommons.org/licenses/by-nc-sa/4.0/), allowing third parties to copy and redistribute the material in any medium or format and to remix, transform, and build upon the material, provided the original work is properly cited and states its license. 


\section{Introduction}

In the 20th century, the social security issue gained a global dimension. A low level of social security results first of all from lack of employment security. The high level of unemployment and decreasing incomes are the main uncertainty factors. Other determinants of social security are:

- lack of financial stability, including anxiety about personal property e.g. which can decrease in value as a result of changes,

- lack of permanent employment connected with lack of active forms of fighting with the unemployment of educated people,

- lack of permanence in social relations, what results in deprecating of acquired profession (the acquired profession is unnecessary),

- lack of social peace.

Currently all over the world, an increased uncertainty and anxiety can be observed due to unemployment, worse remuneration, and decreasing labour market flexibility. The above factors confirm that we are dealing with a low level of social security, which is an arrangement of relations which should be corrected (Leszczyński 2008, 2009, 2011; Żukrowska 2006; Kołodko 2009).

Differences in the level of social security depend on the following determinants: the territorial location and the size of the locality, age group, types of socio-economic groups, and type of household. Social security level is diversified territorially and socially.

The main aim of this article is to analyse the territorial and social diversity of social security in Poland in years 2010-2014. The hypothesis for this present study is that social security level in Poland is diversified with regard to the territorial and social determinants.

Social security means all actions of the state for the citizens that provide them with the minimal living conditions. Its sources should be work, social benefits, and such institutions as health care and education, among others.

It is possible to examine social security from two points of view: financial and nonfinancial. The financial aspect comprises providing citizens with essential resources to live off work or on social security benefits, as well as protecting their health and ensuring education access. The nonfinancial aspect means a cohesive legal system in case of a difficult life situation or a threat to one's life.

In the analyses of economic inequality, the same statistical measures are used as those to examine economic prosperity. The measures employed can be divided into micro- and macroeconomic ones. The gross domestic product per capita is the most often used index. Other measures used for evaluating economic inequality are disposable household income, number of occupants per room and per car, number of work hours per year, and share of expenses for welfare services in GDP.

Microeconomic indexes concern disposable incomes which are allocated for the consumption of

\section{Wstęp}

W XX wieku problem bezpieczeństwa socjalnego zyskał wymiar globalny. Niski poziom bezpieczeństwa socjalnego wynika przede wszystkim z braku pewności zatrudnienia. Głównym czynnikiem niepewności jest wysoki poziom bezrobocia oraz niskie dochody. Inne czynniki warunkujące bezpieczeństwo socjalne to:

- brak stabilności statusu materialnego, w tym obawa o majątek, który może np. w wyniku zmian stracić na wartości,

- brak trwałości zatrudnienia związanego z brakiem aktywnych form zwalczania bezrobocia dla osób wykształconych,

- brak trwałości relacji społecznych, których skutkiem może być zdeprecjonowanie posiadanego zawodu (wyuczony zawód jest niepotrzebny).

- brak spokoju społecznego,

- brak równowagi rynkowej.

Aktualnie na całym świecie obserwuje się wzrost niepewności egzystencji z uwagi na bezrobocie, gorsze wynagrodzenie, elastyczność rynku pracy. Powyższe czynniki potwierdzają, że mamy do czynienia z niskim poziomem bezpieczeństwa socjalnego. Bezpieczeństwo jest więc układem relacji, które należy poprawić.

Różnice $w$ poziomie bezpieczeństwa socjalnego zależą w duży stopniu od następujących czynników: położenia terytorialnego oraz wielkości miejscowości, od grupy wiekowej, grupy społeczno-ekonomicznej oraz typu gospodarstwa domowego. Poziom bezpieczeństwa socjalnego jest więc zróżnicowany terytorialnie oraz społecznie.

Niniejsza praca ma na celu analizę zróżnicowania terytorialnego oraz społecznego bezpieczeństwa socjalnego w Polsce w latach 2010-2014. Hipoteza pracy brzmi: poziom bezpieczeństwa socjalnego w Polsce jest zróżnicowany pod względem terytorialnym i społecznym.

Bezpieczeństwo socjalne to wszelkie działania państwa mające na celu zapewnienie obywatelom minimalnych warunków życia. Źródłem tego powinna być praca, świadczenia społeczne oraz takie instytucje jak m.in. służba zdrowia, oświata.

Bezpieczeństwo socjalne można rozpatrywać w dwóch aspektach materialnym oraz pozamaterialnym. Aspekt materialny obejmuje zapewnienie obywatelom niezbędnych do życia środków, poprzez pracę lub świadczenia socjalne, zapewnienie ochrony zdrowia, edukacji itp. Aspekt pozamaterialny to spójny system praw na wypadek trudnej sytuacji życiowej obywateli oraz w razie zagrożenia ich życia.

W analizach nierówności ekonomicznej wykorzystuje się dane dotyczące tych samych mierników statystycznych wykorzystywanych w badaniu dobrobytu ekonomicznego społeczeństwa. Wykorzystywane mierniki można podzielić na mikroekonomiczne i makroekonomiczne. Najczęściej wykorzystywanym miernikiem jest wielkość Produktu Krajowego Brutto na 1 mieszkańca. Inne mierniki wykorzystywane przy ocenie nierówności ekonomicznej to dochody dyspozycyjne gospodarstw domowych, liczba mieszkańców na 1 izbę mieszkalną, na 1 samochód, roczny czas pracy, udział wydatków na opiekę społeczną w PKB. 
goods and services as well as savings. It is assumed that inequality in income distribution is reflected in economic inequality.

The Gini coefficient, which describes income disproportions is most often used in international comparisons of economic inequality. The rate fluctuates from 0 to $1(0 \%$ to $100 \%)$. The coefficient value is equal 0 when all members of the examined group have equal incomes. Value 1 means that all the income goes to 1 member of this group. The value of the indicator is higher if the degree of income concentration is greater resulting in greater income disparity.

For years Scandinavian countries have been characterized by the lowest Gini coefficient, which is about 0.25 . South African countries have the highest Gini coefficient values. The rate estimated for this region is about 0.6 .

An upward tendency of the Gini coefficient is alarming. Quite violent changes have been observed since 1980. One exception to this tendency was observed in Latin America, where the high Gini coefficient in the first decade of the $21^{\text {st }}$ century started falling. In spite of growing disproportions in income distribution between people in individual
Mierniki mikroekonomiczne dotyczą dochodów rozporządzalnych gospodarstw domowych na który składają się dochody pieniężne i niepieniężne oraz towary i usługi otrzymane nieodpłatnie. Dochód dyspozycyjny jest przeznaczany na wydatki konsumpcję dóbr i usług oraz na przyrost oszczędności.

Zakłada się, że nierównomierności w rozkładzie dochodów są odzwierciedleniem nierówności ekonomicznej. Mierniki zróżnicowanie w rozkładach dochodów są miarami nierówności ekonomicznej.

Najczęściej używanymi miernikami w międzynarodowych porównaniach nierówności ekonomicznej jest współczynnik Giniego, który jest wykorzystywany najczęściej przy opisywaniu dysproporcji dochodów. Rozpiętość współczynnika waha się od 0 do 1 . Wartość współczynnika wynosi 0 , gdy wszyscy członkowie badanej grupy mają równe dochody. Wartość 1 oznacza, że cały dochód trafia do 1 członka tejże grupy. Im wyższa jest wartość wskaźnika, tym większy jest stopień koncentracji dochodów a w jego wyniku większe nierówności osiąganych dochodów.

Od lat najmniejszymi wartościami współczynnika Giniego charakteryzują się kraje skandynawskie. Wartości te wynosza ok. 0,25. Najwyższymi wartościami współczynnika Giniego charakteryzują się kraje Afry-

Table 1. Overall trends in income inequality: summary results for the entire population

Tabela 1. Ogólne trendy zmian nierówności ekonomicznej - zmiany wartości współczynnika Giniego w podziale dochodów

\begin{tabular}{|c|c|c|c|c|c|c|c|}
\hline $\begin{array}{l}\text { Period/ } \\
\text { Okres }\end{array}$ & $\begin{array}{c}\text { Down } \\
\text { a lot/ } \\
\text { Duży spadek } \\
(>0.12)\end{array}$ & $\begin{array}{c}\text { Down }(0.07 \\
\text { to } 0.12) / \\
\text { Spadek (od } \\
7 \% \text { do } 12 \%)\end{array}$ & $\begin{array}{c}\text { Down a bit } \\
(0.02 \text { to } \\
0.06) / \\
\text { Mały spadek } \\
\text { (od 2\% do } \\
6 \%)\end{array}$ & $\begin{array}{l}\text { No change } \\
\text { (to } 0.01 \text { )/ } \\
\text { Brak zmian } \\
\text { (o } 1 \% \text { ) }\end{array}$ & $\begin{array}{c}\text { Up a bit }(0.02 \\
\text { to } 0.06) / \\
\text { Mały wzrost } \\
\text { (od 2\% do } \\
6 \%)\end{array}$ & $\begin{array}{c}\text { Up (0.07 to } \\
0.12) / \\
\text { Wzrost (od } \\
7 \% \text { do } 12 \%)\end{array}$ & $\begin{array}{c}\text { Up a lot } \\
(>12 \%) / \\
\text { Duży wzrost } \\
(>12 \%)\end{array}$ \\
\hline $\begin{array}{l}\text { Mid-1970s to } \\
\text { mid-1990s/ } \\
\text { Od poł. lat } 70 . \\
\text { do poł. lat } 90 .\end{array}$ & $\begin{array}{l}\text { Greece/ } \\
\text { Grecja }\end{array}$ & & $\begin{array}{l}\text { Canada } \\
\text { Finland/ } \\
\text { Kanada } \\
\text { Finlandia }\end{array}$ & \begin{tabular}{|l} 
Japan \\
Mexico \\
Sweden/ \\
Japonia \\
Meksyk \\
Szwecja
\end{tabular} & $\begin{array}{l}\text { Australia/ } \\
\text { Australia }\end{array}$ & \begin{tabular}{|l|} 
Netherlands \\
United States/ \\
Holandia \\
USA
\end{tabular} & $\begin{array}{l}\text { United } \\
\text { Kingdom/ } \\
\text { W. Brytania }\end{array}$ \\
\hline $\begin{array}{l}\text { Mid-1970s to } \\
\text { mid-1980s/ } \\
\text { Od poł. lat } 70 \\
\text { do poł. lat } 80\end{array}$ & $\begin{array}{l}\text { Greece/ } \\
\text { Grecja }\end{array}$ & $\begin{array}{l}\text { Finland/ } \\
\text { Finlandia }\end{array}$ & $\begin{array}{l}\text { Canada } \\
\text { Japan } \\
\text { Mexico } \\
\text { Sweden/ } \\
\text { Kanada } \\
\text { Japonia } \\
\text { Meksyk } \\
\text { Szwecja } \\
\end{array}$ & & $\begin{array}{l}\text { Netherlands/ } \\
\text { Holandia }\end{array}$ & \begin{tabular}{|l|} 
Australia \\
United States/ \\
Australia \\
USA
\end{tabular} & $\begin{array}{l}\text { United } \\
\text { Kingdom/ } \\
\text { W. Brytania }\end{array}$ \\
\hline $\begin{array}{l}\text { Mid-1980s to } \\
\text { mid-1990s/ } \\
\text { Od poł. lat } \\
\text { 80. do poł lat } \\
90 .\end{array}$ & & & $\begin{array}{l}\text { Australia } \\
\text { Denmark } \\
\text { Hungary } \\
\text { Ireland/ } \\
\text { Australia } \\
\text { Dania } \\
\text { Irlandia }\end{array}$ & \begin{tabular}{|l} 
Austria \\
Canada \\
France \\
Greece \\
United States/ \\
Austria \\
Kanada \\
Francja \\
Grecja \\
USA \\
\end{tabular} & $\begin{array}{l}\text { Belgium } \\
\text { Germany } \\
\text { Japan } \\
\text { Mexico } \\
\text { Sweden/ } \\
\text { Belgia } \\
\text { Niemcy } \\
\text { Japonia } \\
\text { Meksyk } \\
\text { Szwecja } \\
\end{array}$ & $\begin{array}{l}\text { Finland } \\
\text { Netherlands } \\
\text { Norway } \\
\text { United } \\
\text { Kingdom/ } \\
\text { Finlandia } \\
\text { Holandia } \\
\text { Norwegia } \\
\text { W. Brytania }\end{array}$ & \begin{tabular}{|l} 
Italy \\
Turkey/ \\
Włochy \\
Turcja
\end{tabular} \\
\hline
\end{tabular}

Source: M. Förster, M. Pearson, Income Distribution and Poverty in the OECD Area: Trends and Driving Forces, "OECD Economic Studies", 2002/34, p. 9.

Źródło: M. Förster, M. Pearson, Income Distribution and Poverty in the OECD Area: Trends and Diving Forces, "OECD Economic Studies", 2002, nr 34, s. 9. 
countries, this disproportion is generally decreasing between countries. Poorer countries are slowly equalizing the standard of living compared with rich countries.

Analysing the above data, we can state that according to the Gini coefficient Greece and Finland recorded the biggest decrease in income inequality. Finland's rank, as an example of a Scandinavian welfare state country, is not surprising, but that of Greece is. The change in the Gini coefficient was an effect of the rise in income amongst the poorest part of the society. Unfortunately, this had disadvantageous results for Greece's economic situation in the first decades of the 21st century. Next, the biggest increase of the Gini coefficient occurred in Great Britain, Italy, and Turkey.

The analysis of the level of the Gini coefficient in the European Union countries indicates that this rate fluctuates around 0.3 . The biggest declines occurred in the new EU member states. In 2006, this value was 0.33 . Then within 5 years, it dropped to 0.303 , which constituted slightly less than the indicator for the "old" European Union countries. ki Południowej. Współczynnik dla tego regionu szacuje się na ok. 0,6.

Niepokojąca jest tendencja wzrostowa współczynnika Giniego. Dość gwałtowne jego zmiany obserwuje się od 1980 roku. Jedynym wyjątkiem od obowiązującej na świecie tendencji rosnącego zróżnicowania pomiędzy krajami bogatymi i biednymi jest Ameryka Łacińska, gdzie wysoki współczynnik Giniego w pierwszej dekadzie XXI wieku zaczął spadać. Należy zauważyć, że pomimo rosnacych dysproporcji w podziale dochodu pomiędzy ludźmi w poszczególnych krajach, maleje dysproporcja pomiędzy samymi krajami. Kraje biedniejsze powoli wyrównują poziom życia w porównaniu z krajami bogatymi.

Analizując powyżej przedstawione dane należy stwierdzić, że największy spadek w podziale dochodów według współczynnika Giniego odnotowała Grecja i Finlandia. 0 ile Finlandia jako przykład kraju Skandynawskiego, czyli kraju prowadzącego politykę państwa opiekuńczego, nie budzi zdziwienia to Grecja już tak. Wyraźny wzrost wskaźnika Giniego był efektem wzrostu dochodów wśród najuboższej części społeczeństwa. Niestety miało to niekorzystne przełożenie na sytuację ekonomiczną kraju pod koniec pierwszej dekady XXI wieku. Z kolei największy wzrost wskaźnika Giniego charakteryzował Wielką Brytanię, Włochy i Turcję.

Analizując poziom wskaźnika Giniego w krajach Unii Europejskiej należy stwierdzić, że wskaźnik ten oscyluje w granicach 0,30. Największy jego spadek miał miejsce w przypadku nowych krajów członkowskich. W roku 2006 wynosił on 0,33 . Spadł w przeciągu 5 lat do 0,303 co stanowiło nawet nieco mniej niż wskaźnik dla krajów „starej” Unii Europejskiej.

Table 2. Gini coefficient of equivalised disposable income (source: SILC) for years 2006-2014

Tabela 2. Wskaźnik Giniego dla krajów Unii Europejskiej (źródło SILC) w latach 2006-2014

\begin{tabular}{|c|c|c|c|c|c|c|c|c|c|}
\hline & $\mathbf{2 0 0 6}$ & $\mathbf{2 0 0 7}$ & $\mathbf{2 0 0 8}$ & $\mathbf{2 0 0 9}$ & $\mathbf{2 0 1 0}$ & $\mathbf{2 0 1 1}$ & $\mathbf{2 0 1 2}$ & $\mathbf{2 0 1 3}$ & $\mathbf{2 0 1 4}$ \\
\hline $\begin{array}{c}\text { EU (27 countries)/ } \\
\text { UE (27 krajów) }\end{array}$ & 0.302 & 0.306 & 0.308 & 0.304 & 0.305 & 0.308 & 0.306 & 0.305 & 0.309 \\
\hline $\begin{array}{c}\text { EU (15 countries)/ } \\
\text { UE (15 krajów) }\end{array}$ & 0.295 & 0.302 & 0.307 & 0.304 & 0.305 & 0.309 & 0.307 & \\
\hline $\begin{array}{c}\text { New member states } \\
\text { (12 countries)/ } \\
\text { Nowe państwa członkow- } \\
\text { skie (12 krajów)/ }\end{array}$ & 0.330 & 0.318 & 0.313 & 0.307 & 0.303 & 0.305 & 0.303 & \\
\hline
\end{tabular}

Source: own elaboration on the basis of Eurostathttp://epp.eurostat.ec.europa.eu/tgm/table.do?tab=table \&plugin=1\&language $=$ en $\&$ pcode $=$ tessi190

Źródło: opracowanie własne na podstawie danych Eurostat http://epp.eurostat.ec.europa.eu/tgm/table.do?tab=table\&plugin= 1\&language $=$ en $\&$ pcode $=$ tessi190

In 2010, the smallest income diversity was in Slovenia (0.238), Sweden (0.241), and Hungary (0.241), while the biggest was in Lithuania (0.369), Latvia (0.361), and Spain (0.339). Analysis showed that Norway and Slovenia had the lowest levels of inequality (as measured by the Gini coefficient) in Europe in 2012, and that Spain and Latvia had the highest levels (Di Falco, 2014).

These data confirm that the value of the Gini coefficient was the highest for the group of countries that entered the European Community in 2004 and
W 2010 r. najmniejsze zróżnicowanie dochodów odnotowano w Słowenii (23,8\%), Szwecji $(24,1 \%)$ i na Węgrzech $(24,1 \%)$ zaś największe na Litwie $(36,9 \%)$, Łotwie $(36,1 \%)$ i w Hiszpanii $(33,9 \%)$. Analizy pokazują, iż Norwegia i Słowenia charakteryzowały się najniższym poziomem nierówności (mierzonym wskaźnikiem Giniego) w Europie w 2012 roku, zaś w Hiszpanii i na Łotwie wskaźnik ten był najwyższy (Di Falco, 2014).

Dane potwierdzają, iż wartość wskaźnika Giniego była najwyższa dla grupy krajów przyjętych do 
later. In Latvia this indicator was almost 0.40 in 2006. Slightly lower indicators, (but nevertheless higher than the European Union average for this period, which was 0.295), were typical in Hungary, Poland, Romania, and Bulgaria. Slovakia, the Czech Republic, and Slovenia had a much lower Gini coefficient than the EU average. The indicator for Slovenia is still the lowest in the Community, and fluctuates around 0.23 .
Wspólnoty Europejskiej w roku 2004 i później. Wskaźnik ten na Łotwie w 2006 roku wynosił prawie 40\%. Nieco niższe wskaźniki, (ale mimo wszystko wyższe od średniej w tym okresie dla Unii Europejskiej, która wynosiła 29,5\%), charakteryzowały Węgry, Polskę, Rumunię i Bułgarię. Co ciekawe Słowacja, Republika Czeska i Słowenia posiadały wskaźniki Giniego znacznie niższe od przeciętnej dla UE. Wskaźnik Słowenii jest wiąż najniższym wskaźnikiem dla kraju Wspólnoty i oscyluje w granicy $23 \%$.

Table 3. Gini coefficient in EU countries for years 2006-2014 (in \%)

Tabela 3. Wskaźniki Giniego w poszczególnych krajach Unii Europejskiej w latach 2006-2014 (wartości w \%)

\begin{tabular}{|c|c|c|c|c|c|c|c|c|c|}
\hline & 2006 & 2007 & 2008 & 2009 & 2010 & 2011 & 2012 & 2013 & 2014 \\
\hline Belgium/ Belgia & 27.8 & 26.3 & 27.5 & 26.4 & 26.6 & 26.3 & 26.6 & 25.9 & 25.9 \\
\hline Bulgaria/ Bułgaria & 31.2 & 35.3 & 35.9 & 33.4 & 33.2 & 35 & 33.6 & 35.4 & 35.4 \\
\hline Czech Republic/Republika Czeska & 25.3 & 25.3 & 24.7 & 25.1 & 24.9 & 25.2 & 24.9 & 24.6 & 25.1 \\
\hline Denmark/ Dania & 23.7 & 25.2 & 25.1 & 26.9 & 26.9 & 27.8 & 28.1 & 26.8 & 27.7 \\
\hline Germany/ Niemcy & 26.8 & 30.4 & 30.2 & 29.1 & 29.3 & 29.0 & 28.3 & 29.7 & 30.7 \\
\hline Estonia/ Estonia & 33.1 & 33.4 & 30.9 & 31.4 & 31.3 & 31.9 & 32.5 & 32.9 & 35.6 \\
\hline Ireland/ Irlandia & 31.9 & 31.3 & 29.9 & 28.8 & 33.2 & 29.8 & 29.9 & 30.0 & 30.8 \\
\hline Greece/ Grecja & 34.3 & 34.3 & 33.4 & 33.1 & 32.9 & 33.6 & 34.3 & 34.4 & 34.5 \\
\hline Spain/ Hiszpania & 31.2 & 31.3 & 31.3 & 32.3 & 33.9 & 34.0 & 35 & 33.7 & 34.7 \\
\hline France/ Francja & 27.3 & 26.6 & 29.8 & 29.9 & 29.8 & 30.8 & 30.5 & 30.1 & 29.2 \\
\hline Croatia/ Chorwacja & --- & --- & --- & --- & 31.6 & 31.2 & 30.9 & 30.9 & 30.2 \\
\hline Italy/ Włochy & 32.1 & 32.2 & 31.0 & 31.5 & 31.2 & 31.9 & 31.9 & 32.8 & 32.4 \\
\hline Cyprus/ Cypr & 28.8 & 29.8 & 28.3 & 29.1 & 29.1 & 29.2 & 31 & 32.4 & 34.8 \\
\hline Latvia/ Łotwa & 39.2 & 35.4 & 37.7 & 37.4 & 36.1 & 35.2 & 35.7 & 35.2 & 35.5 \\
\hline Lithuania/ Litwa & 35.0 & 33.8 & 34.0 & 35.5 & 36.9 & 32.9 & 32 & 34.6 & 35.0 \\
\hline Luxembourg/ Luksemburg & 27.8 & 27.4 & 27.7 & 29.2 & 27.9 & 27.2 & 28 & 34.0 & 28.7 \\
\hline Hungary/ Węgry & 33.3 & 25.6 & 25.2 & 24.7 & 24.1 & 26.9 & 26.9 & 28.3 & 28.6 \\
\hline Malta/ Malta & 27.0 & 26.3 & 27.9 & 27.2 & 28.4 & 27.4 & 27.1 & 27.9 & 27.7 \\
\hline Netherlands/ Holandia & 26.4 & 27.6 & 27.6 & 27.2 & 25.5 & 25.8 & 25.4 & 25.1 & 26.2 \\
\hline Austria/ Austria & 25.3 & 26.2 & 26.2 & 25.7 & 26.1 & 26.3 & 27.6 & 27.0 & 27.6 \\
\hline Poland/ Polska & 33.3 & 32.2 & 32.0 & 31.4 & 31.1 & 31.1 & 30.9 & 30.7 & 30.8 \\
\hline Portugal/ Portugalia & 37.7 & 36.8 & 35.8 & 35.4 & 33.7 & 34.2 & 34.5 & 34.2 & 34.5 \\
\hline Romania/Rumunia & --- & 38.3 & 35.9 & 34.5 & 33.5 & 34.0 & 33.2 & 34.6 & 34.7 \\
\hline Slovenia/ Słowenia & 23.7 & 23.2 & 23.4 & 22.7 & 23.8 & 23.8 & 23.7 & 24.4 & 25.0 \\
\hline Slovakia/ Słowacja & 28.1 & 24.5 & 23.7 & 24.8 & 25.9 & 25.7 & 25.3 & 24.2 & 26.1 \\
\hline Finland/ Finlandia & 25.9 & 26.2 & 26.3 & 25.9 & 25.4 & 25.8 & 25.6 & 25.4 & 25.6 \\
\hline Sweden/Szwecja & 24.0 & 23.4 & 24.0 & 24.8 & 24.1 & 24.4 & 24.8 & 24.9 & 25.4 \\
\hline Great Britain/ Wielka Brytania & 32.5 & 32.6 & 33.9 & 32.4 & 33.0 & 33 & 32.8 & 30.2 & 31.6 \\
\hline
\end{tabular}

Source: Eurostat Database http://epp.eurostat.ec.europa.eu/tgm/table.do?tab=table\&plugin=1\&language=en\&pcode=tessi190

Źródło: Dane Eurostat http://epp.eurostat.ec.europa.eu/tgm/table.do?tab=table\&plugin=1\&language=en\&pcode=tessi190

Among the European Union countries, in terms of the Gini coefficient Poland is placed between such countries as Germany, France, Italy, and Ireland. The decreasing tendency seems positive however the Gini coefficient in Poland is higher than the average for countries of the European Union.

The highest Gini coefficient, so the highest disproportion in incomes, is typical for the Central region of Poland. The average is 0.336 and exceeds the Gini coefficient for the whole country. Only the South-western and Northern regions have a higher rate than 0.30 . The Gini coefficient for other regions
Tabela numer 3 przedstawia zestawienie porównujące wskaźnik Giniego w poszczególnych krajach UE w latach 2006-2014. W zestawieniu widać iż, wśród krajów Unii Europejskiej Polska, pod względem wartości współczynnika Giniego, plasuje się między takimi państwami jak Niemcy, Francja, Włochy i Estonia. Pozytywna wydaje się tendencja malejąca, jednak mimo wszystko wskaźnik Giniego w Polsce jest wyższy niż średnia dla krajów Unii Europejskiej.

Najwyższy wskaźnik Giniego, czyli największy rozłam w dochodach, charakteryzuje region centralnej Polski. Wynosi on 0.336 i znacznie zawyża współczyn- 
Table 4. Selected social cohesion indicators by regions (NUTS 1) based on EU-SILC 2014 (The reference period for income is the year 2013)

Tabela 4. Wskaźnik Giniego według regionów (NUTS 1) w Polsce w oparciu o badanie EU-SILC 2014 (rokiem odniesienia dla zmiennych dotyczących dochodów jest rok 2013)

\begin{tabular}{|c|c|c|}
\hline $\begin{array}{c}\text { Regions (NUTS 1)/ } \\
\text { Regiony (NUTS 1) }\end{array}$ & $\begin{array}{c}\text { Gini Coefficient (in \%)/ } \\
\text { Współczynnik Giniego (w \%) }\end{array}$ & $\begin{array}{c}\text { At-risk-of-poverty rate after social } \\
\text { transfers (in \%)/ } \\
\text { Wskaźnik zagrożenia ubóstwem po } \\
\text { transferach społecznych (w \%) }\end{array}$ \\
\hline Central/ Centralny & 33.6 & 14.1 \\
\hline Southern/ Południowy & 28.2 & 13.5 \\
\hline Eastern/ Wschodni & 29.9 & 22.5 \\
\hline North-western/ Północno-zachodni & 29.3 & 16.2 \\
\hline South-western/ Południowo-zachodni & 30.7 & 15.2 \\
\hline Northern/ Północny & 30.7 & 21.2 \\
\hline Poland/ Polska & $\mathbf{3 0 . 8}$ & $\mathbf{1 7 . 0}$ \\
\hline
\end{tabular}

Source: Incomes and living conditions of the population in Poland (report from the EU-SILC survey of 2014), Warsaw, 2015, p. 178.

Źródło: Dochody i warunki życia ludności Polski (raport z badania EU-SILC 2014), GUS, Warszawa 2015, s. 178.

oscillates around 0.29 . The at-risk-of-poverty rate after social transfers is the highest in the Eastern Region. The value in 2014 was $22.5 \%$ and greatly exceeds the average for Poland.

Observing world tendencies, we can state that (Kuszewski, 2008):

1. in some OECD countries, like Belgium, Denmark, Ireland, South Korea, Norway, Sweden, Great Britain, and the USA, the level of the economic inequality remained stable at the end of the 1990s, although the values for each were different;

2. lower economic inequality was in countries of Central Europe, Scandinavian countries, and Belgium;

3. at the beginning of the 1990's, the highest economic inequality concerned the populations of Mexico and New Zealand;

4. the economy transformation from centrally planned to free market caused an increase in the inequality in Slovakia and Poland, but not in the Czech Republic nor Hungary.

In countries monitoring social security levels including Poland, different measures are applied in order to measure the standard of living. The most important are those used to determine the at-riskof-poverty index. The statutory and relative at-riskof-poverty threshold are determined with respect to the value. It is the specific amount for 1 person in the household.

At-risk-of-poverty indexes in Poland in years $2005-2014$ fluctuated around $16-18 \%$, which is shown in the following figure. The blue line is the abject at-risk-of-poverty index, and the orange line presents the relative at-risk-of-poverty index. The green line shows the statutory at-risk-of-poverty index. nik Giniego w relacji dla całego kraju. Jedynie jeszcze region południowo-zachodni posiada współczynnik wyższy niż 0.30 . Pozostałe regiony charakteryzuje wskaźnik oscylujący granicach 0.29 .

Obserwując tendencje na świecie należy stwierdzić, że (Kuszewski, 2008):

1. W niektórych krajach OECD takich, jak Belgia, Dania, Irlandia, Korea Południowa, Norwegia, Szwecja, Wielka Brytania oraz USA, poziom nierówności ekonomicznej pozostawał w końcu lat 90. na stałym poziomie, chociaż różnym co do wartości.

2. Najmniejsza nierówność ekonomiczna była odnotowana w krajach Europy Środkowej, krajach skandynawskich oraz Belgii.

3. Na początku lat 90. największa nierówność ekonomiczna dotykała ludności Meksyku i Nowej Zelandii.

4. Transformacja gospodarki z centralnie planowanej $\mathrm{w}$ wolnorynkową spowodowała wzrost nierówności na Słowacji i w Polsce, ale nie w Czechach i na Węgrzech.

W krajach monitorujących poziom bezpieczeństwa socjalnego, w tym również w Polsce, stosuje się różne mierniki dla pomiaru stopy życiowej. Najważniejsze to miary stosowane dla wyznaczania stopy ubóstwa. Ustawową i relatywną granicę ubóstwa wyznacza się wartościowo. Jest to określona kwota na 1 osobę w gospodarstwie domowym.

Stopy ubóstwa w Polsce w latach 2005-2014 oscylowały wokół $16-18 \%$ co przedstawia poniższy wykres. Linia niebieska to stopa ubóstwa skrajnego, natomiast linia pomarańczowa przedstawia stopę ubóstwa relatywnego. Linia zielona to ustawowa granica ubóstwa. 


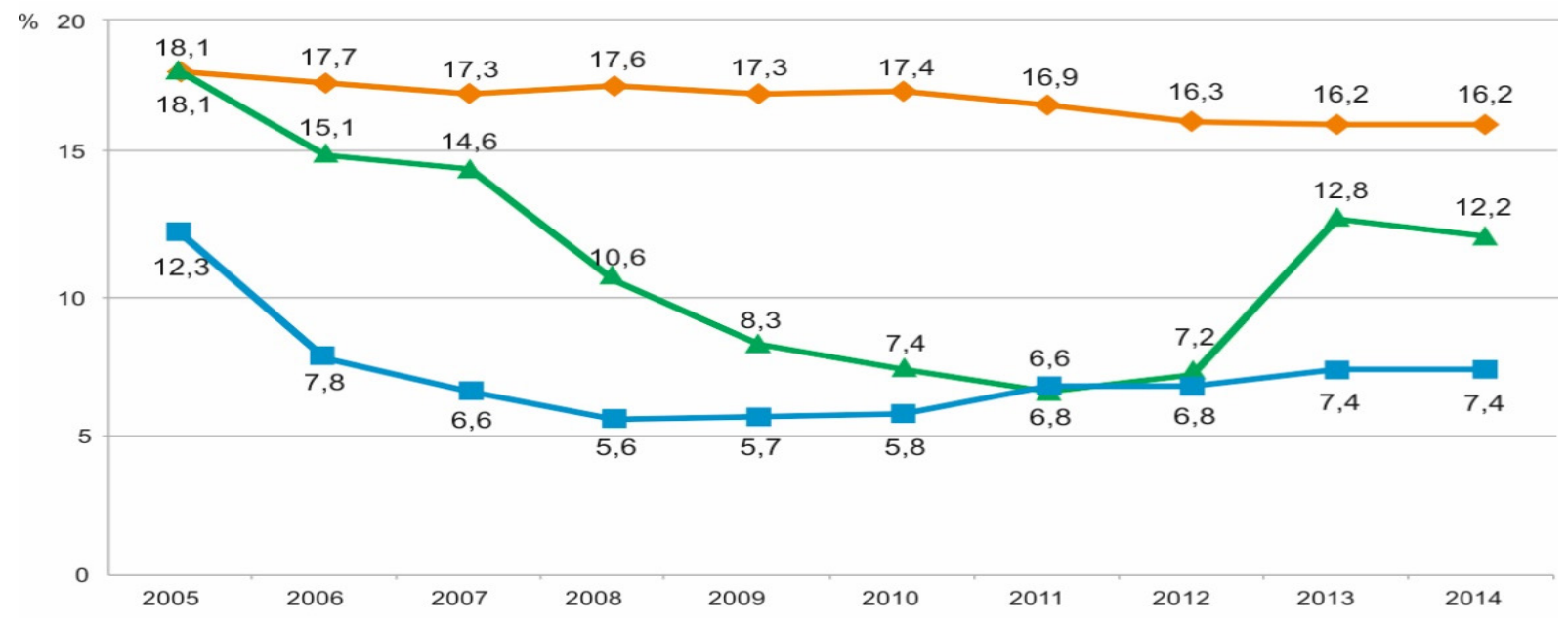

Figure 1. At-risk-of-poverty indexes in Poland in the years 2005-2014

Rysunek 1. Stopy ubóstwa w Polsce w latach 2005-2014

Source: Poverty in Poland in years 2013 and 2014, Central Statistical Office of Poland, Warsaw 2015, p. 9.

Źródło: Ubóstwo w Polsce w latach 2013 i 2014, GUS, Warszawa, 2015, s. 9.

\section{Research methodology}

In recent years, systematic research concerning the reach and social diversification of poverty in the European Union has been conducted. Poverty is a multidimensional socioeconomic phenomenon caused both by aggregate factors such as macroeconomic, social and labour policies and by individual factors like level of education, health, or social interaction in society (Grundiza, Lopez Vilaplana, 2013). The research results are made available as part of research of incomes and the living conditions of the population in all European Union countries, called in short from the English name EU-SILC (EU Statistics on Income and Living Conditions). Research is conducted cyclically; the last took place in the years 2010, 2012 and 2014.

\section{Territorial diversification of social security}

Territorial differences in the level of social security depend to a large degree on two factors: territorial location and the size of the town. In the regional depiction of Poland, the poorest regions at the same time the ones with the lowest level of social security, are located in the east and north of the country. The abject at-risk-of-poverty indicator in the Eastern region is on average 9.5\% of persons per household. The average for the entire country amounts to $6.7 \%$. The lowest threat of abject poverty concerns the south-west, south and central regions. The situation is similar in the case of the threat of the at-risk-of-poverty rate after social transfers by regions indicator. In this case, regions with the highest level of the indicator are the eastern region $(22.5 \%)$ and the north region $(21.2 \%)$. The average for the country is much lower and amounts to $17 \%$ of persons per household. The region with the lowest level of the indicator is the central region (14.1\%).

\section{Metodologia badań}

W ostatnich latach prowadzone są systematyczne analizy dotyczące zasięgu i społecznego zróżnicowanie ubóstwa w Unii Europejskiej. Ubóstwo jest wielowymiarowym zjawiskiem społeczno-ekonomicznym uwarunkowanym zarówno czynnikami makroekonomicznymi i społecznymi oraz czynnikami indywidualnymi takimi jak poziom edukacji i opieka zdrowotna (Grundiza, Lopez Vilaplana, 2013). Wyniki analiz są udostępniane $\mathrm{w}$ ramach badań dochodów i warunków życia ludności we wszystkich krajach Unii Europejskiej zwanego w skrócie od angielskiej nazwy EU-SILC (EU Statistics on Income and Living Condition). Badania są przeprowadzane cyklicznie. Ostatnie miały miejsca w latach 2010, 2012 i 2014.

\section{Terytorialne zróżnicowanie bezpieczeństwa socjalnego}

Terytorialne różnice $\mathrm{w}$ poziomie bezpieczeństwa socjalnego zależą $\mathrm{w}$ duży stopniu od dwóch czynników: położenia terytorialnego oraz wielkości miejscowości. W ujęciu regionalnym w Polsce najuboższe regiony, a zarazem te które cechuje najniższy stopień bezpieczeństwa socjalnego, to region wschodni oraz północny. Wskaźnik zagrożenia ubóstwem skrajnym w regionie wschodnim wynosi 9,5\% osób w gospodarstwach domowych. Średnia dla całego kraju wynosi 6,7\%. Najmniejsze odsetki osób żyjących w gospodarstwach zagrożonych ubóstwem skrajnym obejmowały regiony południowo-zachodni, południowy i centralny. Sytuacja podobna ma miejsce w przypadku wskaźnika zagrożenia ubóstwem relatywnym. W tym przypadku regiony o najwyższym poziomie wskaźnika to region wschodni $(22,5 \%)$ oraz region północny $(21,2 \%)$. Srednia dla całego kraju jest znacznie niższa i wynosi $17 \%$ osób w gospodarstwach domowych. Region o najniższym poziomie wskaźnika to region centralny $(14,1 \%)$. 


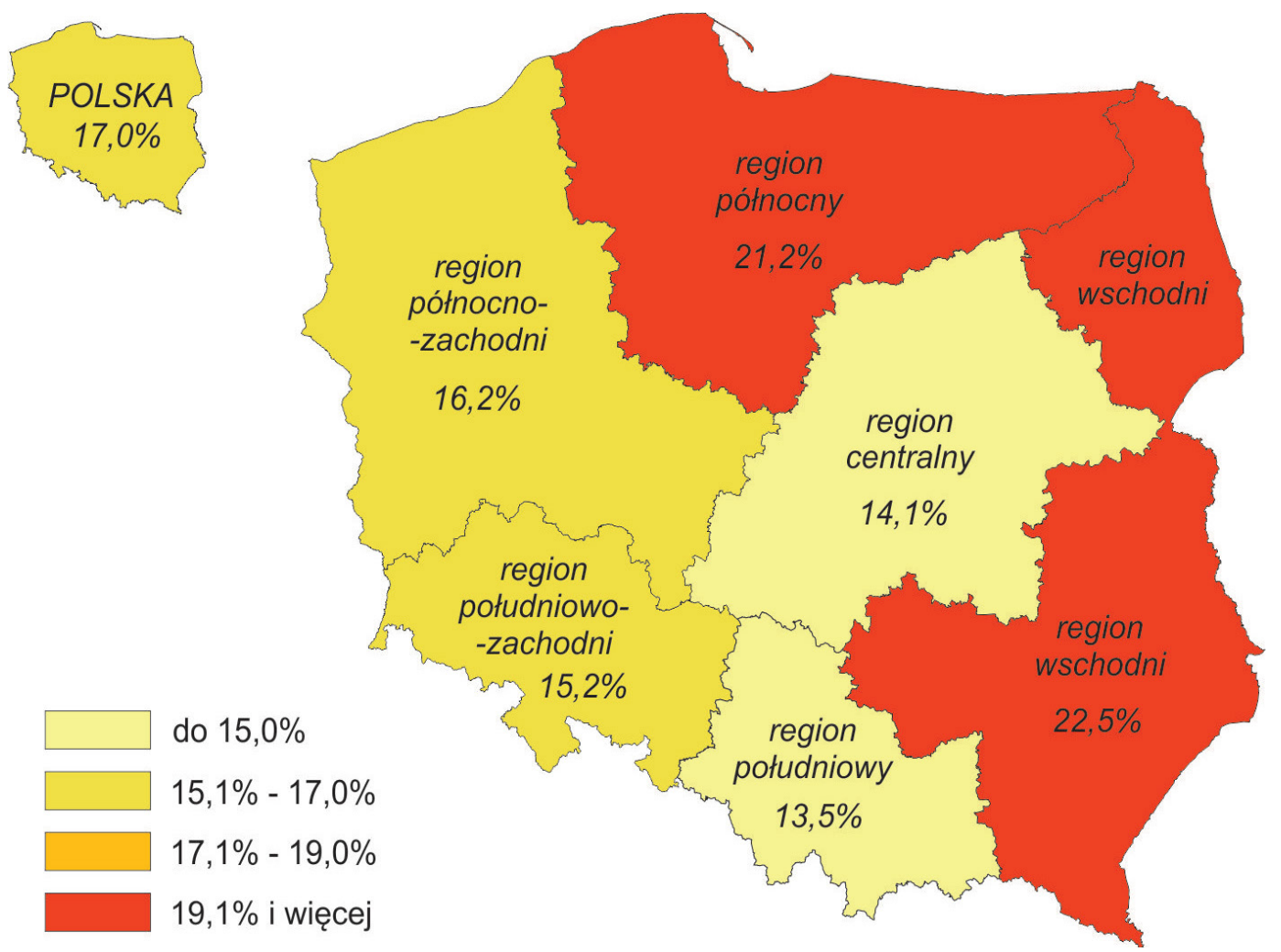

Figure 2. At-risk-of-poverty rate after social transfers by regions (NUTS 1) based on EU-SILC 2014 (in \%) (The reference period for income is the year 2013)

Rysunek 2. Wskaźnik zagrożenia ubóstwem po transferach społecznych według regionów (NUTS 1) w oparciu o badanie EU-SILC 2014 (w \%) (rokiem odniesienia dla zmiennych dotyczących dochodów jest rok 2013)

Source: Central Statistical Office of Poland, http://stat.gov.pl

Źródło: Główny Urząd Statystyczny http://stat.gov.pl

After analysing the situation in individual provinces in Poland, we can state that economic poverty in 2014 mostly concerned the following north-east and eastern provinces: WarmianMasurian, Podlaskie and Świętokrzyskie. The indicator of abject at-risk-of-poverty threat concerned more than $10 \%$ households in these provinces. Whereas the relative at-risk-of-poverty included from $23 \%$ to over $25 \%$ of households in the Warmian-Masurian province. The statutory poverty included around $17.2 \%$ of persons living in households in the Świętokrzyskie province and approx. 21\% in the Warmian-Masurian province.

Provinces in which the abject at-risk-of-poverty threat is the lowest are: Lower Silesian, Opole, Silesian, Lesser Poland, Masovian, and Lubusz. The abject at-risk-of-poverty index was the lowest in the Silesian province in 2014 and amounted to $4.7 \%$. In the remaining provinces mentioned it was about $6-7 \%$. Relative poverty concerned persons from $11.9 \%$ of households (the Silesian province) up to $12 \%$ (Lesser Poland province). There is a peculiar situation in the Masovian province. One can see a clear difference between the capital city Warsaw and the rest of the province. For the Masovian province (without Warsaw), the values of the indicators were similar to averages for Poland.
Analizując sytuację w poszczególnych województwach w Polsce należy stwierdzić, że ubóstwo ekonomiczne w 2014 roku najbardziej dotyczyło następujących województw z Polski północno-wschodniej i wschodniej: warmińsko-mazurskiego, podlaskiego i świętokrzyskiego. Wskaźnik zagrożenia ubóstwem skrajnym (minimum egzystencji) dotyczył w tych województwach ponad $10 \%$ gospodarstw domowych. Ubóstwo relatywne obejmowało zaś od 23\% do ponad $25 \%$ gospodarstw domowych w województwie warmińsko-mazurskim. Sfera ubóstwa ustawowego obejmowała ok. 17,2\% osób w gospodarstwach domowych mieszkających w województwie świętokrzyskim i ok. $21 \%$ w województwie warmińsko-mazurskim.

Województwa, w których zagrożenie gospodarstw domowych ubóstwem skrajnym jest najniższe to: dolnośląskie, opolskie, śląskie, małopolskie, mazowieckie i lubuskie. Wskaźnik ubóstwa skrajnego najniższy był w województwie śląskim i w roku 2014 wynosił $4,7 \%$. W pozostałych wymienionych województwach wahał się w granicach 6-7\%. Ubóstwo relatywne dotyczyło od 11,9\% osób w gospodarstwach domowych (województwo śląskie) do $12 \%$ (województwo małopolskie). Sytuacja specyficzna ma miejsce w przypadku województwa mazowieckiego. Widać tu wyraźną rozbieżność pomiędzy stolicą Warszawą a resztą województwa. Dla województwa mazowieckiego (bez 
A similar situation may also take place in other provinces with major urban centres. However, because of the smaller size of the sample results, those numbers cannot be precisely estimated.

\section{Social diversification of social security}

The second factor affecting social security level is the size of the town. Statistical data confirm that lower poverty is characteristic of a population inhabiting major cities and poverty is characteristic above all of people inhabiting small towns. The data below confirms this situation. In cities with a population above 500000 about $1 \%$ of persons live below the abject at-risk-of-poverty threshold. Whereas in the case of rural area residents, this percentage increases tenfold and is approx. $12 \%$. This tendency unfortunately deepens the diversity in the standard of living between major cities and small towns. In 2014, compared with the previous two years, abject at-risk-of-poverty deepened in the smallest cities (about 1.3\%), in urban areas by approx. 1.2 percentage points, and in cities with residents counting from 20 to 100 thousand by 2 percentage points. However, in major cities part of the persons living in households recognised extremely poor was slightly diminished or reached a similar level as in the previous two years.
Warszawy) wartości wskaźników były zbliżone do średnich dla Polski. Podobna sytuacja może mieć także miejsce w przypadku innych województw z dużymi ośrodkami miejskimi. Jednak ze względu na mniejszą liczebność próby wyniki tych badań nie mogą być precyzyjnie oszacowane.

\section{Społeczne zróżnicowanie bezpieczeństwa socjalnego}

Drugim czynnikiem mającym wpływ na poziom bezpieczeństwa socjalnego jest wielkość miejscowości. Dane statystyczne potwierdzają, iż niższy stopień ubóstwa charakteryzuje ludność zamieszkującą duże miasta. Ubóstwo zaś charakteryzuje przede wszystkim osoby zamieszkujące mniejsze miejscowości. Potwierdzają to dane zamieszczone $\mathrm{w}$ poniższej tabeli. W miastach o liczbie mieszkańców powyżej 500 tys. około 1\% osób żyje poniżej granicy ubóstwa skrajnego (minimum egzystencji). Zaś w przypadku mieszkańców wsi odsetek ten wzrasta 10-krotnie i wynosi ok. $12 \%$. Tendencja ta niestety zmierza w kierunku pogłębienia zróżnicowania poziomu życia w dużych miastach i małych miejscowościach. W 2014 roku, w porównaniu z poprzednim rokiem, pogłębiło się skrajne ubóstwo w najmniejszych miastach (o ok. 1,3 pkt. \%), na wsi o ok. 1,2 pkt. \% i a miastach liczących od 20 do 100 tys. mieszkańców o ok. 2 pkt. \%. Natomiast $\mathrm{w}$ większych miastach odsetek osób żyjących $\mathrm{w}$ gospodarstwach domowych uznanych za skrajnie ubogie nieznacznie zmalał, bądź kształtował się na podobnym poziomie co $\mathrm{w}$ roku poprzednim.

Table 5. At-risk-of-poverty-rate in Poland in 2010-2014 (according to place of residence)

Tabela 5. Wskaźnik zagrożenia ubóstwem ekonomicznym w latach 2010-2014 według miejsca zamieszkania

\begin{tabular}{|c|c|c|c|c|c|c|}
\hline \multirow{3}{*}{$\begin{array}{l}\text { Specification/ } \\
\text { Wyszczególnienie }\end{array}$} & \multicolumn{6}{|c|}{$\begin{array}{l}\text { \% of persons in households with spending less than/ } \\
\% \text { osób w gospodarstwach domowych o wydatkach poniżej }\end{array}$} \\
\hline & \multicolumn{2}{|c|}{$\begin{array}{c}\text { Abject at-risk-of-poverty rate } \\
\text { threshold/ } \\
\text { Granicy ubóstwa skrajnego }\end{array}$} & \multicolumn{2}{|c|}{$\begin{array}{l}\text { Relative at-risk-of-poverty } \\
\text { rate threshold/ } \\
\text { Relatywnej granicy ubóstwa }\end{array}$} & \multicolumn{2}{|c|}{$\begin{array}{l}\text { Statutory at-risk-of-poverty } \\
\text { rate threshold/ } \\
\text { Ustawowej granicy ubóstwa }\end{array}$} \\
\hline & 2010 & 2014 & 2010 & 2014 & 2010 & 2014 \\
\hline $\begin{array}{c}\text { Total/ } \\
\text { OGÓŁEM }\end{array}$ & 5.7 & 7.4 & 17.1 & 16.2 & 7.3 & 12.2 \\
\hline $\begin{array}{l}\text { Urban areas/ } \\
\text { Miasta razem }\end{array}$ & 3.4 & 4.6 & 11.9 & 11.0 & 4.4 & 8.0 \\
\hline \multicolumn{7}{|c|}{$\begin{array}{l}\text { numer of inhabitants:/ } \\
\text { o liczbie mieszkańców: }\end{array}$} \\
\hline $\begin{array}{c}500000 \text { and more/ } \\
\text { i więcej }\end{array}$ & 0.9 & 1.0 & 3.7 & 3.4 & 1.1 & 2.3 \\
\hline $200-500$ & 3.5 & 3.2 & 10.4 & 9.6 & 4.2 & 6.5 \\
\hline $100-200$ & 4.4 & 3.7 & 12.6 & 9.4 & 5.2 & 6.8 \\
\hline $20-100$ & 3.1 & 5.1 & 12.2 & 11.6 & 4.2 & 8.9 \\
\hline less/poniżej 20000 & 5.4 & 8.5 & 19.0 & 18.8 & 7.1 & 13.4 \\
\hline Rural areas/Wieś & 9.4 & 11.8 & 25.4 & 24.4 & 11.9 & 18.7 \\
\hline
\end{tabular}

Source: Poverty in Poland, Central Statistical Office of Poland, Warsaw 2013, p. 19; Tabular appendix to the study Poverty in Poland in 2014, Central Statistical Office of Poland, Warsaw 2015, p. 6.

Źródło: Ubóstwo w Polsce, GUS, Warszawa 2013, s. 19; Tabelaryczny załącznik do Ubóstwa w Polsce w 2014, GUS, Warszawa 2015, s. 6.

The higher at-risk-of-poverty index typical for a population inhabiting small towns is, among others, connected with the lack of ability to find
Wyższy wskaźnik ubóstwa charakteryzujący ludność zamieszkującą mniejsze miejscowości związany jest między innymi z brakiem możliwości znalezie- 
employment. The lack of employment results in the reduced income of the population thus worsening the standard of living. The highest unemployment rate occurs in the regions with the highest at-riskof-poverty index. This relation is quite clear.

In 2014, a growth of the threat of poverty was recorded in almost all socio-economic groups of households. In particular, very disadvantageous changes concerned farmers, amongst whom the percentage of persons in households with expenses below subsistence level rose by 3.1 percentage points. The main reason for this is a decrease in agricultural subsidies by about $40 \%$ as compared with 2010 (The household situation in Poland, 2012). Pensioner households experienced a significant increase in poverty, amongst whom those living below the poverty line grew from $9.6 \%$ up to $12.5 \%$, that is by 2.9 percentage points.

An increase in poverty is a worrying phenomenon among working persons. This increase was slight, a percent constituted only 1.3 pt, however, a tendency confirming an increase in poverty among the employed people in Poland is alarming. nia miejsca pracy. Brak zatrudnienia przekłada się na zmniejszenie dochodów ludności, a więc pogorszenie stopy życiowej. Najwyższa stopa bezrobocia występuje w regionach o najwyższej stopie ubóstwa. Zależność ta jest więc dość wyraźna.

Poziom bezpieczeństwa socjalnego jest zróżnicowany i zależny od grupy wiekowej, grupy społeczno-ekonomicznej oraz typu gospodarstwa domowego.

W roku 2014 odnotowano wzrost zagrożenia ubóstwem w prawie każdej z grup społeczno-ekonomicznych gospodarstw domowych. W szczególności bardzo niekorzystne zmiany dotknęły rolników, wśród których odsetek osób w gospodarstwach domowych o wydatkach poniżej minimum egzystencji wzrósł o 3,1 pkt. proc. Podstawową przyczyną tej sytuacji jest spadek dochodów rozporządzalnych rolników związany ze zmniejszeniem się poziomu dopłat do użytkowanych gospodarstw rolnych o ok. $40 \%$ w porównaniu do roku 2010 (Sytuacja gospodarstw domowych w 2011 r., 2012). Dość znacznie pogorszyła się też sytuacja gospodarstw domowych rencistów, wśród których odsetek osób żyjących poniżej granicy ubóstwa wzrósł z 9,6\% do 12,5\%, czyli o 2,9 pkt. proc.

Szczególnie niepokojącym zjawiskiem jest wzrost ubóstwa wśród osób pracujących. Wzrost ten był niewielki, stanowił zaledwie 1,3 pkt. proc., jednak niepokojąca jest tendencja potwierdzająca wzrost ubóstwa wśród osób zatrudnionych.

Table 6. At-risk-of-poverty-rate in Poland in 2010-2014 (according to socio-economic groups of households)

Tabela 6. Wskaźnik zagrożenia ubóstwem według wybranych grup społeczno-ekonomicznych gospodarstw domowych w Polsce w latach 2010-2014

\begin{tabular}{|c|c|c|c|c|c|c|}
\hline \multirow{3}{*}{$\begin{array}{l}\text { Socio-economic groups } \\
\text { of households/ } \\
\text { Grupy społeczno-eko- } \\
\text { nomiczne gospodarstw } \\
\text { domowych }\end{array}$} & \multicolumn{6}{|c|}{$\begin{array}{l}\text { \% of persons in households with spending less than/ } \\
\% \text { osób w gospodarstwach domowych o wydatkach poniżej }\end{array}$} \\
\hline & \multicolumn{2}{|c|}{$\begin{array}{l}\text { Abject at-risk-of-poverty rate } \\
\text { threshold (substantial level)/ } \\
\text { granicy ubóstwa skrajnego } \\
\text { (minimum egzystencji) }\end{array}$} & \multicolumn{2}{|c|}{$\begin{array}{l}\text { Relative at-risk-of-poverty } \\
\text { rate threshold/ } \\
\text { relatywnej granicy ubóstwa }\end{array}$} & \multicolumn{2}{|c|}{$\begin{array}{l}\text { Statutory at-risk-of-poverty } \\
\text { rate threshold/ } \\
\text { ustawowej granicy ubóstwa }\end{array}$} \\
\hline & 2010 & 2014 & 2010 & 2014 & 2010 & 2014 \\
\hline Workers/ Pracowników & 5.3 & 6.5 & 16.6 & 15.2 & 7.1 & 11.9 \\
\hline Farmers/Rolników & 9.0 & 12.1 & 26.5 & 28.0 & 12.3 & 21.2 \\
\hline $\begin{array}{l}\text { Self-employed/ Pracują- } \\
\text { cych na własny rachunek }\end{array}$ & 2.2 & 4.1 & 9.3 & 8.9 & 3.3 & 6.8 \\
\hline $\begin{array}{l}\text { Senior-citizens/ } \\
\text { Emerytów }\end{array}$ & 3.9 & 5.8 & 13.3 & 12.1 & 4.1 & 7.2 \\
\hline Pensioners/ Rencistów & 9.6 & 12.5 & 25.4 & 25.5 & 10.1 & 17.8 \\
\hline $\begin{array}{l}\text { Living from other non- } \\
\text {-profit sources/ Utrzy- } \\
\text { mujących się z innych } \\
\text { niezarobkowych źródeł }\end{array}$ & 22.4 & 21.1 & 41.9 & 36.2 & 27.0 & 29.9 \\
\hline
\end{tabular}

Source: Poverty in Poland, Central Statistical Office of Poland, Warsaw 2013, p. 18; Tabular appendix to the study Poverty in Poland in 2014, Central Statistical Office of Poland, Warsaw 2015, p. 3.

Źródło: Ubóstwo w Polsce, GUS, Warszawa 2013, s. 18. Tabelaryczny załącznik do Ubóstwa w Polsce w 2014, GUS, Warszawa 2015, s. 3.

In 2014, the poverty threat grew in almost all types of households. The biggest increase of poverty was in marriages with 4 and more children. In this type of household, the proportion of persons with expenses below subsistence level rose by 2.9 pt within one year. The highest rate of poverty threat are marriages
W roku 2014 zagrożenie ubóstwem w relacji do prawie wszystkich typów gospodarstw domowych wzrosło. Największy wzrost ubóstwa miał miejsce w przypadku małżeństw z 4 dzieci na utrzymaniu. W tym typie gospodarstw odsetek osób o wydatkach poniżej minimum egzystencji w ciągu roku wzrósł 
with 4 or more children (Central Statistical Office of Poland 2012, 2013, 2014). o 2,9 pkt. proc. Grupą o najwyższym wskaźniku zagrożenia ubóstwem są małżeństwa z liczbą dzieci 4 i więcej (Główny Urząd Statystyczny w Polsce 2012, 2013, 2014).

Table 7. At-risk-of-poverty rate in Poland in 2010-2014 (according to the types of households)

Tabela 7. Wskaźnik zagrożenia ubóstwem w Polsce w latach 2010-2014 (według wybranych typów gospodarstw domowych)

\begin{tabular}{|c|c|c|c|c|c|c|}
\hline \multirow{3}{*}{$\begin{array}{l}\text { Types of households/ } \\
\text { Typy gospodarstw } \\
\text { domowych }\end{array}$} & \multicolumn{6}{|c|}{$\begin{array}{l}\text { \% of persons in households with spending less than/ } \\
\% \text { osób w gospodarstwach domowych o wydatkach poniżej }\end{array}$} \\
\hline & \multicolumn{2}{|c|}{$\begin{array}{l}\text { Abject at-risk-of-poverty } \\
\text { rate threshold (subsistence } \\
\text { level)/ } \\
\text { granicy ubóstwa skrajnego } \\
\text { (minimum egzystencji) }\end{array}$} & \multicolumn{2}{|c|}{$\begin{array}{l}\text { Relative at-risk-of-poverty } \\
\text { rate threshold/ } \\
\text { granicy ubóstwa skrajnego } \\
\text { (minimum egzystencji) }\end{array}$} & \multicolumn{2}{|c|}{$\begin{array}{l}\text { Statutory at-risk-of-poverty } \\
\text { rate threshold/ } \\
\text { granicy ubóstwa skrajnego } \\
\text { (minimum egzystencji) }\end{array}$} \\
\hline & 2010 & 2014 & 2010 & 2014 & 2010 & 2014 \\
\hline Single/ 1 osobowe & 2.0 & 2.3 & 6.6 & 5.5 & 2.4 & 2.2 \\
\hline \multicolumn{7}{|l|}{$\begin{array}{l}\text { Two adults:/ } \\
\text { Małżeństwa: }\end{array}$} \\
\hline $\begin{array}{l}\text { without children/ } \\
\text { bez dzieci na utrzy- } \\
\text { maniu }\end{array}$ & 1.5 & 1.8 & 6.1 & 5.2 & 1.0 & 1.6 \\
\hline $\begin{array}{l}\text { with one dependent } \\
\text { child/ } \\
\text { z } 1 \text { dzieckiem }\end{array}$ & 1.9 & 2.7 & 7.5 & 6.4 & 1.9 & 3.6 \\
\hline $\begin{array}{l}\text { with two dependent } \\
\text { children/ } \\
\text { z } 2 \text { dzieci }\end{array}$ & 3.9 & 4.5 & 15.1 & 11.2 & 5.4 & 9.0 \\
\hline $\begin{array}{l}\text { with three dependent } \\
\text { children/ } \\
\text { z } 3 \text { dzieci }\end{array}$ & 9.9 & 11.2 & 28.0 & 24.1 & 14.1 & 21.8 \\
\hline $\begin{array}{l}\text { with four or more } \\
\text { dependent children/ } \\
\text { z } 4 \text { dzieci i więcej na } \\
\text { utrzymaniu }\end{array}$ & 24.0 & 26.9 & 44.2 & 48.3 & 34.3 & 47.8 \\
\hline $\begin{array}{l}\text { Single person with de- } \\
\text { pendent children/ } \\
\text { matka lub ojciec z dzieć- } \\
\text { mi na utrzymaniu }\end{array}$ & 7.3 & 5.6 & 17.9 & 14.5 & 10.5 & 12.1 \\
\hline
\end{tabular}

Source: Poverty in Poland, Central Statistical Office of Poland, Warsaw 2012, p. 7; Tabular appendix to the study Poverty in Poland in 2014, Central Statistical Office of Poland, Warsaw 2015, p. 3.

Źródło: Ubóstwo w Polsce, GUS, Warszawa 2012, s. 7; Tabelaryczny załącznik do Ubóstwa w Polsce w 2014, GUS, Warszawa 2015 , s. 3.

The main determinant affecting a family's financial situation is their position on the labour market. Unemployed people and their families are most poverty endangered. In 2014 in households with at least 1 unemployed person, the statutory poverty threat was approx. $44 \%$ of persons, and in households with 2 and more unemployed persons this problem concerned almost every third person. In households with 2 employed parents, this problem concerned only every twentieth person. The abject poverty index was approx. $12.5 \%, 34.5 \%$, and 5\%, respectively (Poverty in Poland, 2012).

The data above confirms that well-paying work does not guarantee avoiding poverty. Low-paying jobs worsen the situation further. This is particularly true for people working as manual labourers. In this group, the abject poverty index in 2012 was approx. $9 \%$. For comparison, in the same time period, only $1.5 \%$ of households with income from white-collar work was found below the poverty line.
Podstawowym czynnikiem wpływającym na sytuację materialną rodziny jest miejsce zajmowane na rynku pracy. Ubóstwem są przede wszystkim zagrożone osoby bezrobotne oraz rodziny osób bezrobotnych. W 2014 roku w gospodarstwach domowych posiadających w swoim składzie co najmniej 1 osobę bezrobotną zagrożonych ubóstwem ustawowym było ok. 44\% osób, a w gospodarstwach z 2 i więcej osobami bezrobotnymi problem ten dotyczył niemal co trzeciej osoby. Z kolei w gospodarstwach bez osób bezrobotnych jedynie co dwudziesta osoba żyła poniżej granicy ubóstwa ustawowego. Stopa ubóstwa skrajnego wynosiła odpowiednio - ok.12,5\%, ok. 34,5\% i ok. 5\% (Ubóstwo $w$ Polsce, 2012),

Powyższe dane potwierdzaja, że wykonywanie pracy zarobkowej nie jest gwarancją uniknięcia ubóstwa. Pogłębianiu się biedy sprzyja wykonywanie pracy niskopłatnej. W szczególności ma to miejsce w przypadku osób czerpiących dochody z pracy najemnej na stanowiskach robotniczych. W przypadku tej grupy 
The analysis of the economic situation of individual age groups (under 18 years of age, 18-64, and 65 and over) indicates that in Poland particularly many professionally active people have low social security (a high level of poverty).

Comparing the three abovementioned age groups, we can state that (In 2010, 23\% of the population...,2012):

- In the European Union, children (aged 0 - 17 years) are at risk of poverty relatively more often than on average. In 2010, the indicator of poverty threat for this group was $26.9 \%$ in the EU countries. In Poland, $30.8 \%$ children were below the poverty line. Poland is one of the countries with the highest poverty threat for children and teenagers.

- The group with the lowest poverty index in the EU were people above 65 years of age. Among elderly people, $19.8 \%$ persons had income below the poverty line. In Poland, the poverty index for this group in a corresponding period was $24.4 \%$.

- Compared to the majority of EU countries, the situation in Poland was the worst. In the population of working persons (aged at least 18 years), the poverty threat index for 27 countries of the European Union was estimated at approx. 24\%. With $27.0 \%$, Poland belonged to the countries with the highest poverty index amongst this group of the population.

The following table presents specific information on poverty risk by age group in the European Union.

The countries with a higher poverty index than in Poland for working persons in 2014 include Bulgaria, Ireland, Greece, Spain, Croatia, Italy, Cyprus, Latvia, Lithuania, Hungary, Portugal and Romania. The poverty threat among persons representing the work force in relation to the society as a whole in the EU countries has unfortunately been growing. It has been possible to observe this adverse trend in the last several years. Generally, the rate of the poverty threat is increasing, and in the case of Poland the biggest increase is in working persons (López Vilaplana, 2013).

The data showing the situation of persons at an economically productive age confirms the disadvantage of Poland in relation to the EU countries. Unfortunately, the situation is even more negative when people who are actually employed are analysed. In this case Poland is in $3^{\text {rd }}$ place in the EU. A less beneficial situation for working persons is only in Romania (19\% of working persons in a group of people threatened with poverty) and Greece $(14 \%)$. The most beneficial situation is in the Czech Republic, where the percentage of the working persons threatened with the poverty is only $3 \%$.

The poverty of working persons can above all result from the imperfections in the labour market (unstable employment, need for part-time work, low salaries, structure of households). The analysis of the relation between the poverty level and the type of employment contracts indicates that in the case of employment contracts, Poland is in $3^{\text {rd }}$ place in osób stopa ubóstwa skrajnego w 2012 roku wyniosła ok. 9\%. Dla porównania w tym samym okresie zaledwie 1,5\% gospodarstw domowych utrzymujących się z dochodów z pracy najemnej na stanowiskach nierobotniczych znajdowało się poniżej granicy ubóstwa.

Analizując sytuację ekonomiczną poszczególnych grup wiekowych, tj. osoby poniżej 18 roku życia, osoby w wieku 18-64 lata oraz osoby w wieku 65 lat i więcej (emeryci) należy stwierdzić, iż w Polsce szczególnie niski poziom bezpieczeństwa socjalnego (wysoki poziom ubóstwa) dotyczy grupy osób aktywnych zawodowo.

Porównując wymienione trzy grupy wiekowe należy stwierdzić, iż (In 2010, 23\% of the population...,2012):

- w Unii Europejskiej relatywnie częściej niż przeciętnie ubóstwem zagrożone są dzieci (osoby w wieku 0 - 17 lat). W 2010 roku wskaźnik zagrożenia ubóstwem dla tej grupy wynosił w krajach UE 26,9\%. W Polsce poniżej granicy ubóstwa żyło 30,8\% dzieci. Polska należała do krajów o najwyższym stopniu zagrożenia ubóstwem dzieci i młodzieży.

- grupą o najniższym wskaźniku ubóstwa w UE były osoby powyżej 65 roku życia. Wśród osób starszych, dochody poniżej granicy ubóstwa miało 19,8\% osób. W Polsce wskaźnik ubóstwa dla tej grupy osób w analogicznym okresie wynosił 24,4\%.

- Niekorzystnie natomiast na tle większości krajów Unii przedstawiała się w Polsce sytuacja osób pracujących. W populacji osób pracujących (w wieku co najmniej 18 lat) wskaźnik zagrożenia ubóstwem dla 27 krajów Unii Europejskiej oszacowano na ok. 23,3\%; Polska, ze wskaźnikiem wynoszącym $27,6 \%$ należała do krajów o najwyższej stopie ubóstwa wśród tej grupy ludności. Szczegółowe informacje przedstawia poniższa tabela.

Kraje, w których stopa ubóstwa wśród osób pracujących w roku 2014 była wyższa niż w Polsce to Bułgaria, Irlandia, Grecja, Hiszpania, Chorwacja, Włochy, Cypr, Łotwa, Litwa, Węgry, Portugalia and Rumunia. Zagrożenie ubóstwem wśród osób reprezentujących zasoby siły roboczej w relacji do całego społeczeństwa w krajach Unii niestety rośnie. Ten niekorzystny trend daje się zaobserwować już na przestrzeni kilkunastu ostatnich lat. Generalnie wskaźnik zagrożenia ubóstwem rośnie, w tym w przypadku Polski największy jego wzrost dotyczy osób pracujących (López Vilaplana, 2013).

Dane przedstawiające sytuację osób w wieku produkcyjnym potwierdzają niekorzystną sytuację Polski na tle krajów unijnych. Niestety sytuacja jest jeszcze gorsza, gdy analizie zostanie poddana grupa osób faktycznie zatrudnionych. W tym przy padku Polska znajduje się na 3 miejscu w UE. Mniej korzystna sytuacja w przypadku osób pracujących ma miejsce tylko w Rumunii (19\% osób pracujących znajduje się w grupie osób zagrożonych ubóstwem) i w Grecji (adekwatnie 14\%). Najkorzystniejsza sytuacja ma miejsce w Republice Czeskiej, gdzie odsetek osób pracujących zagrożonych ubóstwem to zaledwie $3 \%$.

Ubóstwo osób pracujacych może przede wszystkim wynikać z niedoskonałości rynku pracy takich jak mało stabilnego zatrudnienia, konieczności pracy w niepeł- 
Table 8. Population at risk of poverty or social exclusion by age group (in \%), 2014

Tabela 8. Ludność zagrożona ubóstwem lub wykluczeniem społecznym według grup wiekowych (\%), 2014

\begin{tabular}{|c|c|c|c|c|c|}
\hline & $\begin{array}{c}\text { Less than } 16 \\
\text { years/ } \\
\text { poniżej } 16 \\
\text { roku życie }\end{array}$ & $16-24$ & $25-54$ & $\begin{array}{l}55 \text { years or } \\
\text { over/i więcej }\end{array}$ & $\begin{array}{l}\text { Total/ } \\
\text { Razem }\end{array}$ \\
\hline EU28 & 27.4 & 31.6 & 24.1 & 20.9 & 24.4 \\
\hline Belgium/ Belgia & 22.3 & 27.2 & 20.5 & 19.3 & 21.2 \\
\hline Bulgaria/ Bułgaria & 45.2 & 40.9 & 34.9 & 44.2 & 40.1 \\
\hline Czech Republic/ Republika Czeska & 19.3 & 17.3 & 14.1 & 12.8 & 14.8 \\
\hline Denmark/ Dania & 14.4 & 38.2 & 18.6 & 11.5 & 17.9 \\
\hline Germany/ Niemcy & 19.3 & 23.9 & 20.3 & 20.7 & 20.6 \\
\hline Estonia/ Estonia & 23.5 & 23.2 & 21.9 & 33.7 & 26.0 \\
\hline Ireland/ Irlandia & 29.0 & 42.0 & 26.2 & 21.6 & 27.6 \\
\hline Greece/Grecja & 36.0 & 51.0 & 38.4 & 28.9 & 36.0 \\
\hline Spain/ Hiszania & 35.4 & 38.7 & 31.6 & 19.1 & 29.2 \\
\hline France/ Francja & 21.4 & 26.2 & 18.3 & 14.6 & 18.5 \\
\hline Croatia/ Chorwacja & 28.4 & 31.8 & 27.7 & 31.1 & 29.3 \\
\hline Italy/ Włochy & 31.9 & 36.5 & 29.8 & 22.6 & 28.3 \\
\hline Cyprus/ Cypr & 24.6 & 32.1 & 26.7 & 28.0 & 27.4 \\
\hline Latvia/ Łotwa & 34.5 & 32.7 & 28.6 & 37.1 & 32.7 \\
\hline Lithuania/ Litwa & 28.5 & 28.7 & 23.8 & 30.9 & 27.3 \\
\hline Luxembourg/ Luksemburg & 25.7 & 26.2 & 18.1 & 12.5 & 19.0 \\
\hline Hungary/ Węgry & 42.1 & 37.7 & 31.0 & 26.1 & 31.8 \\
\hline Malta/ Malta & 30.9 & 24.1 & 20.9 & 23.9 & 23.8 \\
\hline Netherlands/ Holandia & 17.0 & 26.2 & 17.0 & 11.9 & 16.5 \\
\hline Austria/ Austria & 23.8 & 21.2 & 17.5 & 18.3 & 19.2 \\
\hline Poland/ Polska & 27.4 & 31.3 & 23.6 & 22.3 & 24.7 \\
\hline Portugal/ Portugalia & 30.8 & 34.8 & 26.2 & 25.3 & 27.5 \\
\hline Romania/ Rumunia & 49.6 & 48.6 & 36.5 & 35.2 & 39.5 \\
\hline Slovenia/ Słowenia & 17.6 & 21.5 & 18.7 & 24.2 & 20.4 \\
\hline Slovakia/ Słowacja & 23.4 & 21.1 & 17.6 & 15.8 & 18.4 \\
\hline Finland/ Finlandia & 15.5 & 27.2 & 15.1 & 17.4 & 17.3 \\
\hline Sweden/ Szwecja & 16.3 & 31.5 & 15.1 & 14.5 & 16.9 \\
\hline United Kingdom/ Wielka Brytania & 30.8 & 33.1 & 21.3 & 20.4 & 24.1 \\
\hline Iceland/ Islandia & 14.0 & 11.5 & 11.9 & 7.4 & 11.2 \\
\hline Norway/ Norwegia & 11.7 & 33.5 & 11.8 & 9.3 & 13.5 \\
\hline Switzerland/ Szwajcaria & 17.6 & 15.6 & 12.8 & 21.4 & 16.4 \\
\hline
\end{tabular}

Source: Eurostat Income and living conditions Database http://ec.europa.eu/eurostat/web/income-and-living-conditions/data/ database (dates 18.10.2016).

Źródło: Dane Eurostat Income and living conditions http://ec.europa.eu/eurostat/web/income-and-living-conditions/data/database (data pobrania 18.10.2016). 
Table 9. In-work poverty among employed people (in \%)

Tabela 9. Ubóstwo osób pracujących (w \%)

\begin{tabular}{|c|c|}
\hline Country/ Państwo & $\begin{array}{c}\text { In-work at-risk-of-poverty rate among employed } \\
\text { people, (\%)/ } \\
\text { Odsetek osób zagrożonych ubóstwem w grupie osób } \\
\text { pracujących (\%) }\end{array}$ \\
\hline Romania/ Rumunia & 19 \\
\hline Greece/Grecja & 14 \\
\hline Poland/ Polska & 12 \\
\hline Spain/ Hiszpania & 11 \\
\hline Italy, Latvia, Portugal/ Włochy, Łotwa, Portugalia & 10 \\
\hline Luxembourg/ Luksemburg & 9 \\
\hline $\begin{array}{c}\text { Estonia, Lithuania, United Kingdom/ Estonia, Litwa, } \\
\text { Wielka Brytania }\end{array}$ & 8 \\
\hline Germany, Sweden/ Niemcy, Szwecja & 7 \\
\hline $\begin{array}{l}\text { Bulgaria, Ireland, France, Cyprus, Hungary, Austria/ Buł- } \\
\text { garia, Irlandia, Francja, Cypr, Węgry, Austria, }\end{array}$ & 6 \\
\hline $\begin{array}{l}\text { Holland, Slovenia, Slovakia, Finland/ Holandia, Słowenia, } \\
\text { Słowacja, Finlandia }\end{array}$ & 5 \\
\hline Belgium, Denmark, Malta/ Belgia, Dania, Malta & 4 \\
\hline Czech Republic/ Republika Czeska & 3 \\
\hline
\end{tabular}

Source: Combating poverty and social exclusion. A statistical portrait of the European Union 2010, Publications Office of the European Union, Eurostat Statistical Office, Luxembourg 2010, p. 49.

Źródło: Combating poverty and social exclusion. A statistical portrait of the European Union 2010, Publications Office of the European Union, Eurostat Statistical Office, Luxembourg 2010, s. 49.

Table 10. In-work at-risk-of-poverty rates by type of contract, full/part-time work and months worked, (in \%) Tabela 10. Wskaźnik ubóstwa osób pracujących a rodzaj zawieranych umów o pracę (w \%)

\begin{tabular}{|c|c|c|c|c|c|c|}
\hline \multirow[b]{2}{*}{ Country/Państwo } & \multicolumn{2}{|c|}{$\begin{array}{l}\text { Type of contract/ } \\
\text { Typ umowy }\end{array}$} & \multicolumn{2}{|c|}{$\begin{array}{c}\text { Time worked/ } \\
\text { Czas pracy }\end{array}$} & \multicolumn{2}{|c|}{$\begin{array}{c}\text { Months worked/ } \\
\text { Przepracowany okres }\end{array}$} \\
\hline & $\begin{array}{l}\text { Permanent/ } \\
\text { Zatrudnienie } \\
\text { na czas nie- } \\
\text { określony }\end{array}$ & $\begin{array}{l}\text { Temporary/ } \\
\text { Zatrudnienie } \\
\text { na czas okre- } \\
\text { ślony }\end{array}$ & $\begin{array}{l}\text { Full-time/ } \\
\text { Pełny etat }\end{array}$ & $\begin{array}{c}\text { Part-time/ } \\
\text { Niepełny etat }\end{array}$ & $\begin{array}{c}\text { Full year/ } \\
\text { Cały rok }\end{array}$ & $\begin{array}{c}\text { Less than } \\
\text { a full year/ } \\
\text { Mniej niż cały } \\
\text { rok }\end{array}$ \\
\hline EU - 27 & 5 & 13 & 7 & 12 & 8 & 15 \\
\hline $\begin{array}{l}\text { Romania/ } \\
\text { Rumunia }\end{array}$ & 5 & 20 & 15 & 56 & 18 & 27 \\
\hline $\begin{array}{c}\text { Greece/ } \\
\text { Grecja }\end{array}$ & 5 & 19 & 13 & 27 & 13 & 26 \\
\hline \multicolumn{7}{|l|}{$\ldots$} \\
\hline $\begin{array}{c}\text { Poland/ } \\
\text { Polska }\end{array}$ & 5 & 12 & 11 & 19 & 11 & 18 \\
\hline \multicolumn{7}{|l|}{$\ldots$} \\
\hline $\begin{array}{l}\text { Holland/ } \\
\text { Holandia }\end{array}$ & 3 & 5 & 4 & 4 & 5 & 4 \\
\hline $\begin{array}{l}\text { Czech Republic/ } \\
\text { Republika Czeska }\end{array}$ & 2 & 6 & 3 & 4 & 3 & 7 \\
\hline
\end{tabular}

Source: Combating poverty and social exclusion. A statistical portrait of the European Union 2010, Publications Office of the European Union, Eurostat Statistical Office, Luxembourg 2010, p. 50.

Źródło: Combating poverty and social exclusion. A statistical portrait of the European Union 2010, Publications Office of the European Union, Eurostat Statistical Office, Luxembourg 2010, s. 50.

the EU countries in terms of the poverty of persons employed at a full-time job and working all year. As many as $11 \%$ of such employed persons live in poverty in Poland. The situation is more negative only in Romania and in Greece. For an example, in the Czech Republic the level of poverty in this group of people is 3\% and is much lower than the average for the EU countries, which is about 7\%. The Czech nym wymiarze godzin, niskich płac, struktury gospodarstw domowych. Analizując zależność między poziomem ubóstwa a rodzajem zawieranych umów o pracę należy stwierdzić, że w przypadku umów o pracę Polska znajduje się na 3 miejscu w krajach UE pod względem ubóstwa osób zatrudnionych na pełny etat i pracujących przez cały rok. Aż 11\% tak zatrudnionych osób żyje w Polsce w ubóstwie. Sytuacja gorsza jest tylko 
Republic also has the most beneficial indicator concerning employment based on contracts for an indefinite time. The poverty level in this group of people is $2 \%$ and is the lowest in the entire European Union.

\section{Conclusions}

The main aim of this article was to analyse the territorial and social diversity of social security in Poland in years 2010-2014. The hypothesis that social security level in Poland is diversified under the territorial and social determinants was verified positively.

The analyses for the purpose of this article confirmed that the territorial diversity of social security was dependent on the two factors: the territorial location and the size of the town. The poorest regions in Poland and at the same time with the lowest level of the social security are the eastern and the north region. The lowest percentage of persons living in the households threatened with the abject poverty spread through the south-west, the south and the central regions. As far the size of the town, low poverty level is characteristic of major cities' inhabitants. Poverty is characterises above all persons inhabiting small towns.

The analyses carried out in this article also confirmed that the social diversity of social security was dependent on three factors: age, socio-economic group and the type of the household. Regarding social diversity, the group with the lowest poverty index were persons above 55 years of age. In the population of working persons (at least 18 years old), the poverty threat index for 28 countries of the European Union was estimated at 24\%. Poland, with the index amounting $27.0 \%$, belonged to the countries with the highest poverty index amongst this group of the population.

To sum up, it has to be started that the residents of small cities from the north-east part of the country and persons at the age between 16-24 are most threatened with the poverty. In the case of Poland also a high percentage of the threat of poverty is a matter of concern among working people. The lowest poverty level is in the group of people above 55 years of age, i.e. persons receiving pension benefits. w Rumunii i Grecji. Dla przykładu w Republice Czeskiej poziom ubóstwa w tej grupie osób wynosi zaledwie 3\% i jest dużo niższy niż średnia dla krajów UE, która kształtuje się na poziomie 7\%. Czechy posiadają także najbardziej korzystny wskaźnik dotyczący zatrudnienia na podstawie umów na czas nieokreślony. Poziom ubóstwa w tej grupie osób wynosi zaledwie $2 \%$ i jest najniższy w całej Unii Europejskiej.

\section{Podsumowanie}

Praca miała na celu analizę zróżnicowania terytorialnego oraz społecznego bezpieczeństwa socjalnego w Polsce w latach 2010-2014. Hipoteza postawiona w pracy, iż poziom bezpieczeństwa socjalnego w Polsce jest zróżnicowany pod względem terytorialnym i społecznym została zweryfikowana pozytywnie.

Analizy przeprowadzone na potrzeby opracowania potwierdziły, iż terytorialne zróżnicowanie bezpieczeństwa socjalnego zależne jest od dwóch czynników: położenia terytorialnego oraz wielkości miejscowości. Najuboższe regiony w Polsce, a zarazem te które cechuje najniższy stopień bezpieczeństwa socjalnego, to region wschodni oraz północny. Najmniejsze odsetki osób żyjących w gospodarstwach zagrożonych ubóstwem skrajnym obejmowały regiony południowo-zachodni, południowy i centralny. Biorąc pod uwagę wielkości miejscowości niższy stopień ubóstwa charakteryzuje ludność zamieszkującą duże miasta. Ubóstwo zaś charakteryzuje przede wszystkim osoby zamieszkujące mniejsze miejscowości.

Analizy przeprowadzone na potrzeby opracowania potwierdziły, iż społeczne zróżnicowanie bezpieczeństwa socjalnego zależne jest od trzech czynników: wieku, grupy społeczno-ekonomicznej oraz typu gospodarstwa domowego. Biorąc pod uwagę zróżnicowanie społeczne, grupa o najniższym poziomie zagrożenia ubóstwem to osoby powyżej 55 roku życia. W przypadku 28 krajów Unii Europejskiej w grupie osób pracujących poziom zagrożenia ubóstwem szacowany jest na poziomie $24 \%$. Polska ze wskaźnikiem ok. $27 \%$ należy do państw w których stopień zagrożenia ubóstwem jest najwyższy.

Reasumując należy stwierdzić, iż najbardziej zagrożeni ubóstwem są mieszkańcy małych miast leżących w północno-wschodniej części kraju oraz osoby w przedziale wiekowym 16-24 lata. W przypadku Polski niepokój budzi także wysoki odsetek zagrożenia ubóstwem osób pracujących. Najniższy poziom ubóstwa notowany jest w grupie osób powyżej 55 roku życia, czyli osób pobierających świadczenia emerytalne.

\section{References/ Literatura:}

1. Główny Urząd Statystyczny (2012), Sytuacja gospodarstw domowych w 2011. Materiały Konferencyjne, Warszawa.

2. Główny Urząd Statystyczny (2012), Ubóstwo w Polsce. Warszawa.

3. Combating poverty and social exclusion. A statistical portrait of the European Union 2010 (2010), Publications Office of the European Union, Eurostat Statistical Office, Luxembourg.

4. Di Falco E. (2014), Income inequality: nearly 40 per cent of total income goes to people belonging to highest (fifth) quintile. Statistics in focus, 12, http://ec.europa.eu/eurostat/web/products-statistics-in-focus/-/KS-SF-14-012 (data dostępu 12.06.2016).

5. Dzieci korzystające ze świadczeń pomocy społecznej w Polsce w 2011 r. (2013), GUS Urząd Statystyczny w Krakowie.

6. Förster M., Pearson M. (2002), Income Distribution and Poverty in the OECD Area: Trends and Driving Forces. OECD Economic Studies, 34, https://search.oecd.org/eco/growth/2968109.pdf (data dostępu 18.06.2016). 
7. Grundiza S., Lopez Vilaplana C. (2013), Is the likelihood of poverty inherited? Statistics in focus, 27, http://ec.europa.eu/eurostat/web/products-statistics-in-focus/-/KS-SF-13-027 (data dostępu 15.06.2016).

8. Grusky D., Kanbur R. (2006), Poverty and inequality. Stanford University Press, California USA.

9. In 2010, 23\% of the population were at risk of poverty or social exclusion (2012), Eurostat News release, 21, http://ec.europa.eu/ eurostat/documents/2995521/5152374/3-08022012-AP-EN.PDF/954b7373-e946-4cbd-8b21-540d5e6e9f78 (data dostępu 21.06.2016)

10. Dochody i warunki życia ludności Polski (raport z badania EU-SILC 2014). (2015), GUS, Warszawa.

11. Kołodko G.W. (2008), Wędrujący świat. Prószyński i Spółka, Warszawa.

12. Kuszewski T. (2008), Nierówności ekonomiczne we współczesnym świecie. Pomiar i oceny zjawiska, W: M. Garbicz, W. Pacho (red.), Wzrost gospodarczy a bezrobocie i nierówności w podziale dochodu. Oficyna Wydawnicza SGH, Warszawa, s. 155-179.

13. Leszczyński M. (2008), Bezpieczeństwo socjalne jako obszar zainteresowania badawczego i składnik bezpieczeństwa państwa, W: M. Lisiecki (red.), Zarządzanie bezpieczeństwem - wyzwania XXI wieku. Wyd. Wyższej Szkoły Zarządzania i Prawa, Warszawa, s. 543-558.

14. Leszczyński M. (2009), Bezpieczeństwo społeczne a bezpieczeństwo państwa. Wydawnictwo Uniwersytetu Humanistyczno-Przyrodniczego Jana Kochanowskiego, Kielce.

15. Leszczyński M. (2011), Bezpieczeństwo społeczne a współczesne państwo. Zeszyty Naukowe Akademii Marynarki Wojennej, nr 2 (185), s. 123-132.

16. López Vilaplana C. (2013), Children were the age group at the highest risk of poverty or social exclusion in 2011, Eurostat, Statistics in focus $4 / 2013$.

17. Ludność. Stan i struktura demograficzno-społeczna (2013), Główny Urząd Statystyczny, Warszawa.

18. Stiglitz J., Sen A., Fitoussi J.P. (2009), Report by the Commission on the Measurement of Economic Performance and Social Progress, http://www.stiglitz-sen-fitoussi.fr/en/index.htm (data dostępu 20.02.2016).

19. The EU in the world. 2015 edition (2015). Publications Office of the European Union, Luxembourg.

20. Warunki życia rodzin w Polsce (2014), Główny Urząd Statystyczny, Warszawa.

21. Żukrowska K. (2006), Pojęcie bezpieczeństwa i jego ewolucja, W: K. Żukrowska, M. Grącik (red.), Bezpieczeństwo międzynarodowe. Teoria i praktyka. Wyd. SGH, Warszawa. 